\title{
E-VOTING: SUCCESS AND FAILURES. LESSON FOR AFRICA
}

Ben Beklisi Kwame Ayawli

Sunyani Polytechnic, P. O. Box 206, Sunyani, Ghana

bbkayawli@yahoo.com

Samuel Kojo Kwofie

University of Ghana, P. O. Box L25, Accra, Ghana

skwofie2000@yahoo.com

Stephen Kofi Dotse

Accra Institute of Technology, Accra, Ghana

stephendotse@gmail.com

\section{ABSTRACT}

This study investigated the factors leading to e-voting adoption successes and failures. Secondary data on e-voting adoption across the world was used in this study.

Results indicate that concerns about accuracy, lack of trust, lack of secrecy of votes, lack of verifiability, secrecy of source codes and lack of support from political parties are among the factors leading to failure in e-voting adoption and it vary from country to country.

The findings of this study can help in the determination of the necessary factors for the successful and sustainable adoption of e-voting system.

Keywords: E-voting; Electronic Voting Machines (EVM), NEDAP voting machines; Paper Trail Machines; E-voting Adoption; Elections.

\section{Academic Discipline and Information Technology}

\section{Sub-Disciplines}

E-voting, Application management systems

\section{SUBJECT CLASSIFICATION}

Information Technology

\section{TYPE (METHOD/APPROACH)}

Literature analysis

\section{Council for Innovative Research}

Peer Review Research Publishing System

Journal: International Journal Of Management \& Information Technology

Vol. 10, No 7

editorsijmit@gmail.com

www.ijmit.com 


\section{INTRODUCTION}

African countries including other countries across the world use paper ballot form of voting to elect their leaders. It is believed from reports that paper ballot of voting is accompanied with numerous irregularities including ballot box stuffing, multiple voting, intentional and unintentional miscounts of votes. This is a great challenge for African countries in conducting reliable elections whose results are generally acceptable by their people. This at times leads to political unrest [1]. Many researchers suggested e-voting as a solution to the problems of paper ballots electoral process [2][3][4][5][6][7][8].

Countries like Brazil, India, United States of America and Estonia have chucked numerous successes despite some challenges in the use of e-voting while Paraguay, Germany, Ireland and Netherland had to abandon the use of e-voting [9][10]. USA was the first to adopt and use e-voting as far back in the 1890s however, as at the moment, most states in the US still use paper ballots and there were reports of irregularities in some states where e-voting was used [11] [12][21].

According to [11], there was expectation of majority of states using paper ballots in the past 2012 elections in the United States. He demonstrated the type of e-voting systems used in the United Stated as shown in a map in figure 1.

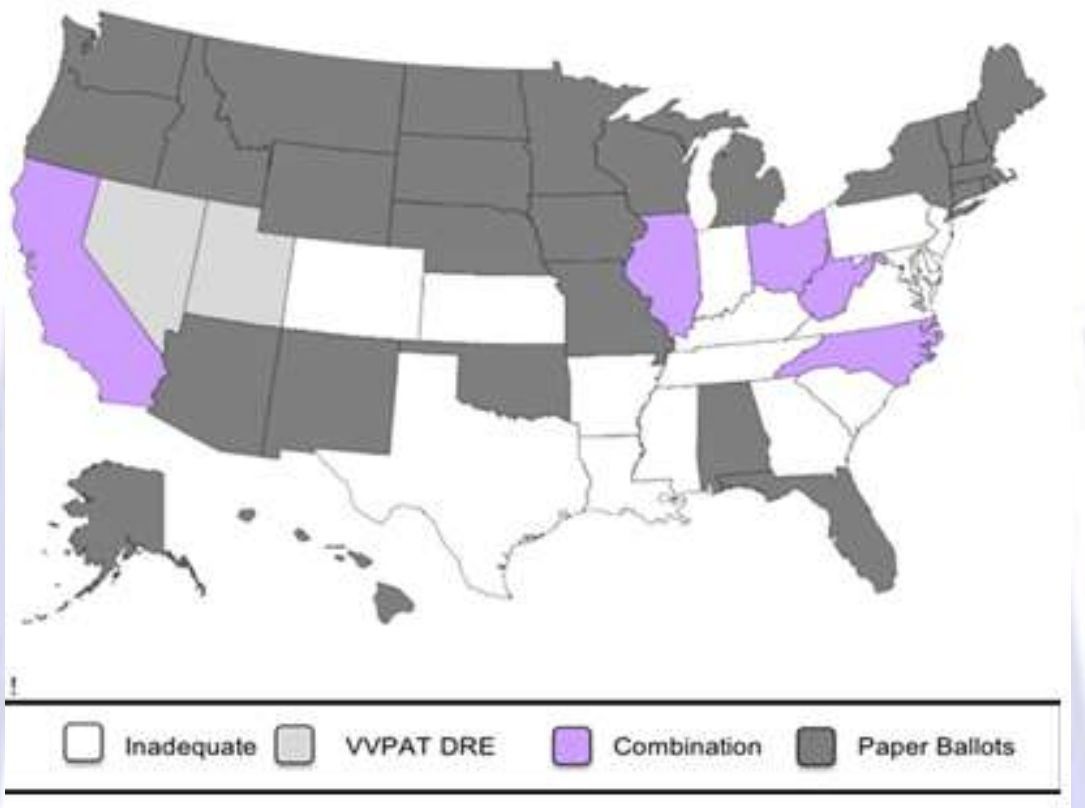

Figure 1: Voting systems used in each state of the United States. (Source: [11].)

From figure 1, it shows that, majority of the states in the United States of America used paper ballots as compared to evoting systems. Even the use of e-voting system in some of the states was described to be inadequate.

Some African countries including Ghana, Kenya and many others have expressed interest in the use of e-voting to alleviate the problems of paper ballots and its associated consequences. The adoption of the technology in elections in Africa has generated a lot of debate with reference to the success stories of Brazil, India and Estonia and the failures of Netherland, Ireland, Paraguay and Germany.

The purpose of this study is to determine the causing factors for adoption success and failures of e-voting in the countries that piloted or adopted the technology and later on abandon its use. The knowledge of the factors leading to e-voting adoption failure in these countries can help determine the necessary factors for the successful and sustainable adoption of e-voting system. The identified factors would be a lesson to prospective African countries expressing interest in electronic voting.

\section{INTERNATIONAL SUCCESS EXPERIENCES OF E-VOTING}

India, Brazil and Estonia are countries who currently use e-voting for their national elections covering the whole country. United State of America currently use e-voting since 1890s for their national elections but they are not considered in this study because most states in the US still use paper ballots [12][21]

\section{India's E-Voting Experience}

Following legal approval in 1989 to allow the use of Electronic Voting Machines (EVMs), they have been used in many state elections but never in an entire general election until 2004. In the 1999 parliamentary poll, the machines, prepared by Electronics Corp of India and Bharat Electronics, were used in 45 constituencies. As the world's largest democracy with a population of more than 1 billion, India has an electorate of more than 668 million and covers 543 parliamentary constituencies, and will require more than one million electronic voting machines (EVMs).Slightly bigger than a laptop, the EVM comprises two units, one for control by the polling staff and the other for the use of voters. The balloting unit requires 
voters to press the button next to the candidate's name and symbol and the control unit records the vote. A light next to the button glows, and a short beep sound follows indicating the vote has been cast. The polling officer then presses a switch to clear the machine for the next voter. The EVM comes in a reusable carry pack, and can operate on a battery power source in remote areas.

E-voting in India has been hailed by many including the Electoral Commission of India to be secure and "temper-proof" as a result of successes chucked over the years in the implementation of e-voting in the general elections including the speed of vote counts, boot capture and reduction of invalid ballots.

In recent years, there have been numerous allegations and press reports of election irregularities involving Indian EVMs. It is difficult to assess the credibility of these charges, since there has apparently never been a prosecution related to EVM fraud, and there has never been a post-election audit to attempt to understand the causes [13]. Nevertheless, they paint a troubling picture of election security in India. Reports of malfunctions have been extensively surveyed by Rao [14]. For instance, he relates that in the 2009 parliamentary election there were reported EVM malfunctions in more than 15 parliamentary constituencies across the country. Especially troubling are claims that when the voter pressed a button for one candidate, a light would flash for another, which could be explained by a simple attack on the EVM cable [13]. According to [14], Rao also relates reports from prominent politicians that engineers approached them in 2009 offering to fix elections through this method.

Despite these incidents, experts for the Election Commission have equated any questioning of the security of the EVMs with an attack on the commission's own impartiality and integrity [13]. On 25th July 2011, responding to a PIL a Writ Petition (Civil) No. 312 of 2011), Supreme Court of India asked EC to consider request to modify EVMs and respond within 3 months. The petitioner Rajendra Satyanarayan Gilda had alleged that EC has failed to take any decision despite his repeated representation. The petitioner suggested that the EVMs should be modified to give a slip printed with the symbol of the party in whose favor the voter cast his ballot [15][16]. On 17 January 2012, Delhi High Court in its ruling on Dr. Subramanian Swamy's Writ Petition (Civil) No. 11879 of 2009 challenging the use of EVMs in the present form said that EVMs are not "tamper-proof". Further, it said that it is "difficult" to issue any directions to the EC in this regard. However, the court added that the EC should itself hold wider consultations with the executive, political parties and other stake holders on the matter [17].

After performing security analysis of India's electronic voting machines, Prasad concluded that in spite of the machine's simplicity and minimal software trusted computing base, it is vulnerable to serious attacks that can alter election results and violate the secrecy of the ballot [14]. They demonstrated two attacks, implemented using custom hardware, which could be carried out by dishonest election insiders or other criminals with only brief physical access to the machines.

Challenges for Electronic Voting in India as documented by [14] include the following.

$\bullet$

well over a million EVMs in use, the cost of the system is a major concern. The current EVMs are built from inexpensive commodity parts and cost approximately $\$ 200$ for each set of units, far less than many DREs used in the U.S., which cost several thousand dollars.

-

Many polling places are located in areas that lack electricity service or have only intermittent service. Thus, the EVMs operate entirely from battery power, rather than merely using a battery as a backup.

Hazards - India's varied climate has great extremes of temperature, as well as other environmental hazards such as dust and pollution. EVMs must be operated under these adverse conditions and must be stored for long periods in facilities that lack climate control. An Election Commission report cites further dangers from "attack by vermin, rats, fungus or due to mechanical danger, [that might cause] malfunction".

-

Though many Indian voters are well educated, many others are illiterate. The country's literacy rate in 2007 was $66 \%$, and only about $55 \%$ among women, so handling illiterate voters must be the rule rather than the exception. Thus, ballots feature graphical party symbols as well as candidate names, and the machines are designed to be used without written instructions.

-

with Technology - Some voters in India has very little experience with technology and may Unfamiliarity by electronic voting. For example, "Fifty-year-old Hasulal Topno impoverished Oraon tribal, who gathers firewood from the forest outlying the Palamau Tiger Reserve, a Maoist hotbed $35 \mathrm{~km}$ from Daltonganj town" told a reporter, "I am scared of the voting machine," prior to its introduction in his village. Nirmal Ho, "a tribal and a marginal farmhand in the Chatarpur block of Palamau district," said he was "more scared of the EVMs than the Maoists" on account of his unfamiliarity with technology [14].

\section{Estonia's E-Voting Experience}

Estonia had started to include the Internet voting option in public elections as early as 2005 in an election for local offices and had offered the first Internet voting on the national level in2007. In 2009, in addition to the European elections in June, the Internet voting option was also offered for local elections in October. And in March 2011, voters could vote online in the national parliamentary elections [18]. 
Estonia is a country of 1.3 million inhabitants and a former Soviet republic on the Baltic Sea. Estonia has a reputation to be the most advanced-society and has the farthest developed e-voting system in Europe. In Estonia, e-Learning, online driver's license tests and mobile payment of bus tickets are a matter of course. Also, Estonia was a victim of a major cyber-attack in 2007 immediately after the national elections, which sensitized the country for matters of e-vulnerability [18].

Estonia has conducted five nationwide elections in which all voters could use Internet voting as an additional voting method. The first election, in October 2005, was for local offices and the overall voter turnout was low, reaching merely $47.4 \%$. Only $1.9 \%$ of the voters made use of the option to vote online in this case. The second election, in March2007, was for parliamentary elections at the national level. The turnout for the 2007elections was approximately $62 \%$, a figure reportedly higher than in the previous two elections held in 2003 and 1999 . The percentage of voters making use of the Internet option in the 2007 election had increased to $5.5 \%$.

After intensive research by [6)], they identified four important reasons for the success of e-voting in Estonia including:

\section{- Widespread Internet penetration}

- A legal structure that addresses Internet voting issues: Today, all Estonians have an identification card which includes a digital certificate (signature) embedded in the card. In combination with a unique personal identification number (PIN) the card can be used for online authentication. The basis for this infrastructure was the Digital Signature Act (DSA) of 2002 which allowed individuals to use approved digital signatures to authenticate themselves in online transactions, including e-government transactions and e-voting.

- An identification system that allows for digital authentication of the voter: First of all, an Estonian voter inserts his or her ID card into the card reader. The electronic ID cards hold the digital signature of the respective person. Digital signatures consist of a private and a public key: The private key is secret and stored on the smart card; the public key is assigned to the identity of the holder of the identity card. After inserting the smart card into the card reader, the voter has to open the voting homepage of the National Electoral Committee in order to download and initiate the voter application. After that, the private key is activated with the submission of a secret PIN. After selecting a candidate from a list and casting the vote, a second PIN is provided and the voted ballot is encrypted.

- A political culture that is supportive of Internet voting: E-voting in Estonia was supported by political elites and the public administration from the beginnings in 2002. The initial proposals for Internet voting were made by the Estonian prime minister and the minister of justice. Their decision to champion this option provided high level support and helped to overcome initial hurdles for implementing Internet voting. Although there have been governmental changes since the initial legislative initiative, Internet voting remains a voting mode that almost all parties support.

\section{Brazil's E-Voting Experience}

Trials of the electronic voting machine began in 1996, with the first tests carried out in the state of Santa Catarina. The primary design goal of the Brazilian voting machine is extreme simplicity, the model being a public phone booth. Brazil is the first country to have deployed electronic voting machines nationwide for elections, and the machines are used for all elections.

Electronic voting in Brazil succeeded in both reducing fraud and enfranchising illiterate voters. While the rate of invalid votes averaged 40 percent before electronic voting, it went down to 7.6 percent in 2002 [4].The Brazilian voting machine consists of two terminals, the first is used by the polling official to authenticate the voter and the second is used by the voter to cast a ballot. Authentication consists of the polling official typing in the ID number of the voter. If the voter is found then the polling official activates the voting terminal to enable the voter to vote. The voting terminal consists of a numerical keyboard and an LCD screen. Voters enter the number of the candidate for whom they wish to vote. The selection is displayed and the voter can confirm the choice or alter it. The voter can also cast a blank ballot. At the end of polling the voting machine produces the results from the polling station. These results are also encrypted and loaded onto a diskette which is taken to a results consolidation center [4].

The Brazilian voting machine accomplishes three steps (voter identification, secure voting and tallying) in a single process, eliminating fraud based on forged or falsified public documents. Political parties have access to the voting machine's programs before the election for auditing. There still remain some questions about the security of the electronic voting system, but no case of election fraud has been uncovered.

Critics argue that the voting machines do not produce receipt for the voter, nor maintain an internal paper based journal which would allow for vote auditing. This makes them highly dependent on trusting the software. The application program which verifies the internal integrity of the system is itself vulnerable to modification. An inspection by the City of Sto Estevão, Bahia described the system of seals and closure of the machine as simple and allowed easy access to the internal memory slot. [19]

Concerns regarding the accuracy of the self-auditing systems caused the legislature to mandate a retrofit of $3 \%$ (some 12,000 machines) to produce a paper ballot that the voter could peruse and deposit in a box for recount. These paper-trail machines were successfully used during the October 6, 2002 election. Following that demonstration of the reliability of the machines, use of the paper trail was abandoned for subsequent 
elections. Following a lengthy debate over the advantages and disadvantages of the paper trail option, the government concluded that eliminating the use of printers within the system would save Brazil about $\$ 100$ million. In addition, moving to all printerless machines would make voting much faster [20].

\section{INTERNATIONAL FAILURE EXPERIENCES OF E-VOTING Ireland E-Voting Experience}

The Irish government began investigating the possible use of electronic voting machines in 1998 but it took until 2002 for electronic voting trials to be conducted. After these trials a decision was taken by the government to implement electronic voting nationwide in the June 2004 European and local elections, with voting machines being procured from NEDAP, a Dutch company, for $€ 53$ million.

However, throughout 2003, opposition grew from civil society and some political parties to the government decision to implement electronic voting. In response to this growing pressure, on March 1, 2004 the government established a Commission on Electronic Voting to report on the secrecy and accuracy of the selected electronic voting system, to review the tests conducted on this system and to make a recommendation on the suitability of the system for use in the June 2004 elections.

The Commission's Interim Report published on 29 April 2004 sent shockwaves through the Irish government by finding that it was, "not in a position to recommend with the requisite degree of confidence the use of the chosen electronic voting system at elections in Ireland in June 2004" [22]. This was due to concerns about the accuracy of the system due to insufficient testing and the fact that changes were still being made to the system, not providing sufficient time to retest the system before its planned use. Concerns were also raised about possible violations of vote secrecy caused by the beeping of the machine and plans to publish full details of all votes cast (lower order preferences under Ireland's single transferable vote electoral system potentially providing a signature for the voter).

The Irish government was left with no choice but to cancel the planned use of its electronic voting machines in the 2004 elections. A first report issued by the Commission on Electronic Voting in December 2004 reiterated the conclusions and recommendations of the Interim Report. It made an additional observation that the voting machines did not have a voter verified audit trail. It said that an audit trail would help audit and build trust in the voting machines, and that in its absence even higher standards of testing were required [22].

The status of electronic voting in Ireland entered a limbo phase after these initial reports of the Commission. The Irish government still wished to pursue the use of electronic voting machines, but could not do so against the recommendation of the Commission. The cost of augmenting the voting machines to make them compliant with the Commission's recommendations was estimated to cost a further $€ 28$ million [23], and this additional expenditure was seen as politically unpalatable.

A Second Report by the Commission in 2006 put another nail in the coffin of electronic voting in Ireland. Elaborating many of the previous findings and adding sections on physical and operational security, and compliance with Council of Europe recommendations on electronic voting, the Commission found that "when compared in terms of secrecy and accuracy, the existing paper system is moderately superior overall to the chosen electronic system as currently proposed for use in Ireland (and in some respects only marginally so). However, the Commission's work has highlighted modifications to the chosen system and the procedural arrangements for its deployment, together with further software analysis and testing of the system as a whole that could potentially remedy this situation." [24]

This measured language of the Commission was seen by many as a damning indictment of the chosen electronic voting system [23]. A formal government decision to end the electronic voting project did not come until April 2009, when the Minister for the Environment, Heritage and Local Government announced that the government had decided not to proceed with the electronic voting project and a decision would be taken on the disposal of the voting machines [25].

\section{Netherlands E-Voting Experience}

The Netherlands was one of the first countries to embrace voting and counting technologies. The 1980s saw the Dutch attempting to automate the counting process with the first electronic voting machines appearing in the early $1990 \mathrm{~s}$. From 1994 the Dutch government started to actively promote the use of electronic voting machines [26]. By the 2006 election 97.7 percent of municipalities were using them. Nedap electronic voting machines were used across the Netherlands. Voters were required to press a touch screen next to the candidate of their choice and then press a red button to confirm their vote. Votes were recorded electronically in each machine and the totals were printed from each machine at the close of voting [27)].

Criticisms of the use of electronic voting machines in the Netherlands started from 2000, with the main concerns being the secrecy of the source code and evaluation reports, and the lack of verifiability of the machines. However, it took developments in Ireland, which were using the same NEDAP machines as the majority of the Netherlands and the introduction of voting machines to the city of Amsterdam, to bring these concerns to fruition. Developments in Ireland led Dutch citizens to start asking similar questions about the suitability of the machines for their own country. In 2006 a pressure group made up of computer scientist hackers called "We Don't Trust Voting Computers" [28], and was led by Rop Gonggrijp [10]. Using freedom of information laws and their technical skills, Gonggrijp's group managed to buy some NEDAP machines and identified in them a number of security flaws, including the easy replacement of program chips 
allowing the results to be manipulated. Due to the lack of verification mechanisms such replacement would go unnoticed. The group also demonstrated the susceptibility to eavesdropping on radio emissions of the voting called the "tempest attack" [34]. A detailed report was released a month before the 2006 election [28].

While some of the security problems could be easily remedied, others were more serious. In response, Wij Vertrouwen Stemcomputers Niet and others called for all electronic voting systems to produce verifiable paper audit trails. Aft er the 2006 election, the question of whether or not the electronic voting system in use had been legally approve d by government reached the courts. In 2006, the government established two committees to look into the issue of electronic voting. Government testing confirmed the group's claims and found that the internet voting system was similarly insecure [27] [10]. In April, 2006 the Voting Machines Decisions Committee issued a report entitled Voting Machines, a neglected dossier. The report listed recommendations for both the short and medium terms about voting machine legislation. Autumn 2006 saw the publication of a report, Voting with confidence, issued by the Advisory Committee on the Voting Process Mechanism, after which the cabinet adopted a position on the matter.

The Advisory Committee's report recommended that due to issues of transparency and verifiability, voting should take place using only paper ballots in polling stations, effectively ending the Netherlands' use of electronic voting machines. While the Committee's report did not rule out the possibility of electronic voting machines in the future, which better met the requirements of elections in the Netherlands, there have been no moves to introduce new electronic voting machines since. After the 2006 election, the question of whether or not the electronic voting system in use had been legally approved by government reached the courts. In September 2007, a Dutch judge declared that it had not approved it [29]. In October 2007 the regulation allowing the use of electronic voting machines was withdrawn and the government of the Netherland has banned electronic voting machines from future elections and the nation had to return to paper ballot voting [10][26]

\section{Paraguay E-Voting Experience}

Paraguay first experimented with the use of electronic voting machines in 2001 through an agreement between the Paraguayan Supreme Electoral Court of Justice and the Supreme Electoral Court of Brazil, which loaned a small number of Brazilian voting machines for trials in local government elections. In 2003, this agreement was extended with 6,000 voting machines being provided for the presidential election, an election where over 50 percent of voters used electronic voting machines. This cooperation was further extended for a series of local elections in the following years, with 16,000 voting machines being loaned to Paraguay and the majority of voters casting ballots using these machines.

Throughout this period, however, opposition from political parties had been growing. As a result, the Supreme Electoral Court of Justice requested the opinions of political parties concerning the future use of electronic voting machines. The majority of opposition political parties opposed the use of electronic voting machines, favoring paper voting. The ruling party only preferred the use of electronic voting machines but did not object to the use of paper ballots. Therefore the decision was taken that the general elections to be held in 2008 would be done solely using paper ballots.

\section{Germany E-Voting Experience}

In 1998 the first electronic voting machines, supplied by the Dutch supplier NEDAP, were trialed in Cologne. The trial was seen as successful and one year later Cologne used electronic voting machines for its entire European Parliament Election [22]. Soon other cities were following suit, and by the 2005 general election nearly two million German voters were using these NEDAP machines to cast a vote [30]. Reaction to the use of these electronic voting machines was generally very positive among voters, who found the machines to be easy to use, and among election administrators, who were able to reduce the numbers of polling stations and staff in each polling station [22].

However, after the 2005 election, two voters brought a case before the German Constitutional Court after unsuccessfully raising a complaint with the Committee for the Scrutiny of Elections. The case concerned the federal election of 2005 in which 39 voting districts in several states used electronic voting machines instead of paper ballots. Some two million votes were cast in this manner [31]. The case argued that the use of electronic voting machines was unconstitutional and that it was possible to hack the voting machines; therefore, the results of 2005 election could not be trusted. In a ruling that was a surprise to many, the German Constitutional Court upheld the first argument that the use of the NEDAP voting machines was unconstitutional [32].According to the Court, the voting machines used in the election did not live up to the constitutional principle of transparency of elections, which requires that voting machines be safeguarded against potential manipulation or error through procedures that are understandable to the average citizen. The Court, however, did not invalidate the election, because there had been no evidence of abuse or error involving the machines [31].

Many have misinterpreted or misquoted this ruling by the Constitutional Court to mean that the use of the electronic voting machine per se is unconstitutional in Germany. This is not the case. The findings of the Court are far more nuanced than this and in no way rule out the use of electronic voting machines. The Court noted that under the constitution elections are required to be public in nature and: "...that all essential steps of an election are subject to the possibility of public scrutiny unless other constitutional interests justify an exception... The use of voting machines which electronically record the voters' votes and electronically ascertain the election result only meets the constitutional requirements if the essential steps of the voting and of the ascertainment of the result can be examined reliably and without any specialist knowledge of the subject... The very wide-reaching effects of possible errors of the voting machines or of deliberate electoral fraud make special precautions necessary in order to safeguard the principle of the public nature of elections." [32]. Making it clear that the decision of the Court did not rule out the use of voting machines in principle, it stated that: 
"The legislature is not prevented from using electronic voting machines in elections if the possibility of a reliable examination of correctness, which is constitutionally prescribed, is safeguarded. A complementary examination by the voter, by the electoral bodies or the general public is possible for example with electronic voting machines in which the votes are recorded in another way beside electronic storage" [32].

The Federal Constitutional Court in Germany decided in 2009 to stop using electronic voting machines because results from the machines were not verifiable [33]. This decision by the German Constitutional Court effectively ended Germany's current use of electronic voting. Although the Court decision does not rule out electronic voting machines entirely, no further moves to adopt machines which meet the transparency requirements have been made.

\section{ANALYSIS OF E-VOTING ADOPTION: SUCCESSES AND FAILURES}

The analysis of the successes and failures of e-voting adoption is summarized in Table 1 and Table 2

Table 1: Analysis of E-voting success in India, Brazil and Estonia

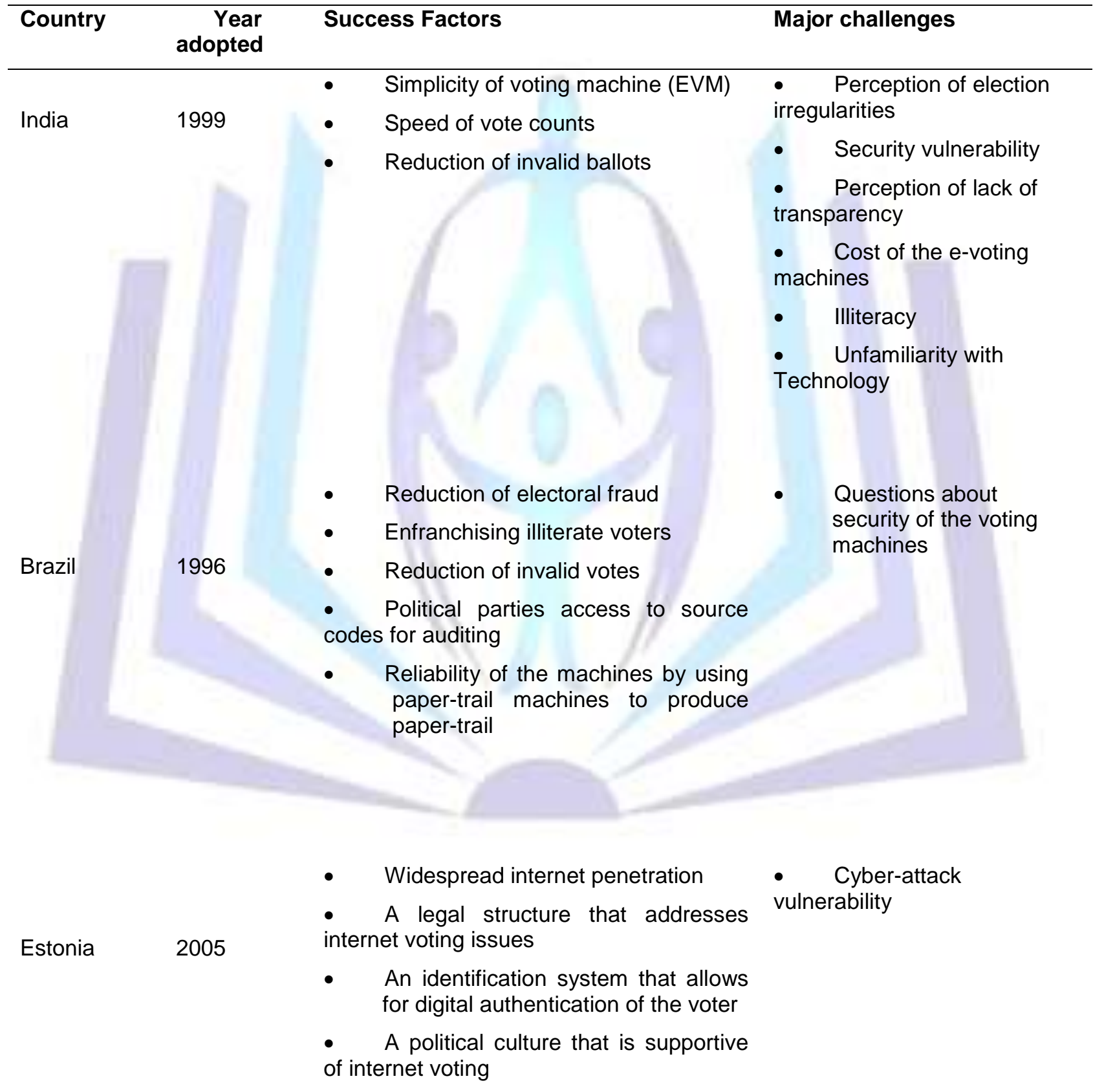


Table 2: Analysis of E-voting failures in Ireland, Netherlands, Paraguay and Germany

\begin{tabular}{|c|c|c|c|}
\hline Country & Year adopted & Year abandoned & Reason of failure \\
\hline \multirow[t]{5}{*}{ Ireland } & 2002 & 2009 & a. Concerns about the accuracy of the voting system. \\
\hline & & & $\begin{array}{l}\text { b. Concerns about possible violations of the vote } \\
\text { secrecy caused by: }\end{array}$ \\
\hline & & & i. the beeping of the voting machine \\
\hline & & & ii. plans to publish full details of all votes cast \\
\hline & & & $\begin{array}{l}\text { C. Concerns about trust due to the absence of a voter } \\
\text { verified audit trail }\end{array}$ \\
\hline \multirow[t]{4}{*}{ Netherlands } & 1994 & 2007 & $\begin{array}{l}\text { a. Concerns about lack of transparency due to secrecy } \\
\text { of the source code and evaluation reports }\end{array}$ \\
\hline & & & b. Lack of verifiability of the machines \\
\hline & & & Lack of trust \\
\hline & & & $\begin{array}{l}\text { d. Concerns raised in Ireland about NEDAP machines } \\
\text { raised questions about the suitability of the use of } \\
\text { the machines in Netherland }\end{array}$ \\
\hline Paraguay & 2001 & 2008 & $\begin{array}{l}\text { Opposition political parties opposed the use of e-voting } \\
\text { machines favoring paper voting }\end{array}$ \\
\hline \multirow[t]{3}{*}{ Germany } & 1998 & 2009 & $\begin{array}{l}\text { a. Concerns about constitutionality of the use of voting } \\
\text { machines. }\end{array}$ \\
\hline & & & $\begin{array}{l}\text { b. Concerns about the possibility of hacking the voting } \\
\text { system (Security) }\end{array}$ \\
\hline & & & c. Lack of transparency \\
\hline
\end{tabular}

\section{CONCLUSIONS AND RECOMMENDATIONS}

It was identified from the analysis that, the causing factors of e-voting adoption failures include: the accuracy of the voting system, transparency, verifiability, trustworthiness, constitutionality, acceptance of election stakeholders including political parties and security issues.

Despite the successes chucked by India, Brazil and Estonia in the adoption and use of e-voting, there are some challenges that needs to be addressed. The challenges differ from one country to the other. However, the basic challenge facing these countries is security; Brazil solved the problem of transparency and reliability by making the source codes available to the political parties and also the use of paper trail machines respectively. Due to widespread penetration of internet, legal structures to deal with internet voting systems, the use of electronic identification system and support of politicians made the adoption and use of e-voting successful in Estonia. The challenge to be addressed is finding ways to strengthen security against cyber-attack.

Inability to deal with concerns about accuracy of the voting system, lack of trust and violations of vote secrecy brought Ireland plans to adopt and use e-voting for their national elections to a halt. Security which is a challenge to Brazil, India and Estonia were a factor that could not make the adoption and use of e-voting in Germany sustainable. Unlike Estonia which was successful because politicians support the e-voting system, it was mainly due to the lack of support from political parties that led Paraguay to abandon the use of e-voting. Transparency issue which was well addressed by Brazil was a factor that caused Netherland and Germany to abandon the use of e-voting system for paper-ballots system. While there is a legal structure in Estonia to address e-voting issues, one of the main factors that led to the abandonment of $e$ voting in Germany is concerns about constitutionality of e-voting machines.

These success and failure factors should be a lesson to African countries and other countries planning to adopt e-voting system. In future research it would be appropriate to determine the effects of these factors including others to the successful and sustainable adoption of e-voting system. 


\section{REFERENCES}

[1] Jegede, et al. 2009. "Electronic Voting": A Panacea for Electoral Irregularities in Developing Countries" Journal of Mobile Communication.

[2] Forounso, O., Sogunseye, O., Okesola, J. O \& Molaniyan, O. 2010. Visualizing E-Voting Results. Journal of Theoritical and Applied Information Technology, Vol. 16.

[3] Haziemeh F.A, Khazaaleh M.K and Al-Talafha K. M. 2011, "New Applied E-Voting System", Journal of Theoretical and Applied Information Technology, Vol. 25 pp. 93

[4] Avgerou, C., Andrea G., Angeliki P., \&Nicolau R. 2009."Interpreting the Trustworthiness of Government Mediated by Informationand Communication Technology: Lessons from Electronic Voting in Brazil. Information Technology for Development 15 (2):133-48.

[5] Barrat, J. (2006). "A preliminary question: Is e-voting actually useful for our democratic institutions? What do we need it for?" In Electronic Voting 2006, ed. R. Krimmer and R. Grimm. Bonn: Gesellschaft fur Informatik.

[6] Alvarez, R.M., Hall, T., Trechsel, A. (2009). Internet Voting in Comparative Perspective: The Case of Estonia", in: Political Science and Politics, Vol. 42, No. 3, p.497-505.

[7] Towns, S. 2008. California put the breaks on e-voting, Government technology, pp.32-36.

[8] Vuyst, B. \& Fairchild, A. 2005. Experimenting with electronic voting registration: the case of Belgium , Electronic journal of e-government, Vol.3, Issue.2, pp.87-90 .

[9] Duncan P. 2012. E-Voting machines to be scrapped. IRISHTIMES.COM. Retrieved June15 ${ }^{\text {th }}, 2012$, from www.irishtimes.com/newspaper/breaking2.html

[10] Loebar, L. 2008a). E-voting in the Netherlands from General Acceptance to General Doubt in Two Years. Electronic Voting 2008 (EVOTE08). $3^{\text {rd }}$ International Conference, CastleHofen, Bregenz, Austria

[11] Lee T.B. 2012. Paper Prophets: Why e-voting is on the decline in the United States. Retrieved Oct 22, 2014 from http://arstechnica.com/features/2012/10/paper-prophets-why-e-voting-is-on-the-decline-in-the-united-states/2/

[12] Longley R. n.d Counting the votes on Election. Retrieved $2^{\text {nd }}$ January, 2015 From www.usgovinfo.about.com/od/thepoliticalsystem/a/votecounts.htm

[13] Rao, G.V. 2010. Democracy at Risk! Citizens for Verifiability, Transparency \& Accountability in Elections, New Delhi. Retrieved June 15, 2012, fromhttp://indianevm.com/book.php

[14] Prasad H.K., Halderman A.J, Goggrijp R, Wolchok S., Wustrow E., Kankipati A., Sakhamuri S. \&Yagati V. 2010. Security Analysis of India Electronic Voting Machines.NetIndia, (P) Ltd, Hyderabad pp. 1 and 20

[15] SC order on EVM".Supreme Court of India. 2011. Retrieved February 15, 2012, from http://courtnic.nic.in/supremecourt/temp/wc\%2031211p.txt

[16] Do EVMs need modification? SC asks EC to decide in 3 weeks. 2011. Retrieved February 15, 2012, from http://www.indianexpress.com/news/do-evms-need-modification-sc-asks-ec-to-decide-in-3-weeks/822122/0

[17] SC asks EC to consider request to modify EVMs. 2011. Retrieved February 15, 2012, from http://articles.timesofindia.indiatimes.com/2011-07-26/india/29816157 1 evms-electronic-voting-suggestions

[18] Science and Technology Options Assessment (STOA). 2011. E-public, e-participation and e-voting in EuropeProspects and Challenges.Final Report.Directorate General for Internal Policies. (IP/A/STOA/FWC-200896/LOT4/C1/SC2)

[19] Andrianantoandro, A. 2010 . "Brazil's Presidential Hopefuls Face Runoff, National Congress Needs Reform". Retrieved 2011-05-04 from www.FairVote.org

[20] Benoit K. 2005. Experience of Electronic Voting Overseas. The Policy Institute, Trinity College Dublin pp 315 -317 Conference, Bregenz, Austria, 7 August. Accessed at: http://www.e-voting.cc/topics/conference2008

[21] Anthony S. 2012. Election day: Why e-voting sounds cool, but will never replace paper ballots. Retrieved: $10^{\text {th }}$ January, 2015 From: www. Extremetech.com/extreme/139660-election-day-why-e-voting-sounds-cool-but-willnever-replace-paper-ballots

[22] Commission on Electronic Voting 2004. Interim Report of the Commission on Electronic Voting on the Secrecy, Accuracy and Testing of the Chosen Electronic Voting System. Retrieved $11^{\text {th }}$ November, 2014 From http:/Ireland.com/newspaper/special/2004/evoting/dar1.pdf

[23] McDermott, R. 2010.“Ireland: A Decade of Electronic Voting”. Direct Democracy: Progress and Pitfalls of Election Technology, IFES: Washington DC. 
[24] Commission on Electronic Voting 2006. Second Report of the commission on Electronic Voting: Secrecy, Accuracy and Testing of the Chosen Electronic Voting System. Retrieved $10^{\text {th }}$ November, 2014 From http:/www.umic.pt/images/stories/pblicacoes1/Part\%200\%20Index.pdf

[25] Esteve J.B, Goldsmith B. \& Turner J. 2012. International Experience with E-voting (Norwegian E-vote Project). International Foundation for Electoral Systems: Washington DC.

[26] Bart J. and Wolter. 2009 "Electronic Voting in the Netherlands: From Early Adoption to Early Abolishment," in Proceedings of FOSAD'2008. Retrieved January 12, 2013 from http://www.dare.ubn.kun.nl/bitstream/2066/75763/1/75763.pdf

[27] OSCE/ODIHR 2007. The Netherlands Parliamentary Elections. 2006 OSCE/ODIHR Election Assessment Mission Report, Warsaw, OSCE/Office for Democratic Institution and Human Rights

[28] Wij Vertrouwen Stemcomputers Niet. 2006. Nedap/Groenendaal ES3B Voting Computer: Security Analysis. Retrieved $8^{\text {th }}$ March, 2014 Fromt: http://wijvertrouwenstemcomputersniet.nl/Nedap-en

[29] Libbenga, J.2007. 'Dutch Pull the Plug on E-Voting', The Register, 1 October.

[30] Speigel 2008. Election Worries: Court to Examine Security of Electronic Voting. Retrieved $5^{\text {th }}$ January, 2015. www.spiegel.de/international/germany/election-worries-court-to-examine-security-of-electronic-voting-a$\underline{587001 . h t m l}$

[31] Palmer E. 2009. Germany: Constitutional Court Decision on Electronic Voting. Retrieved 25 March, 2014 From: http://www.loc.gov/lawweb/servlet/loc news?disp3 1205401164 text

[32] Federal Constitutional Court Stops Electronic Voting Roulette 2009. Retrieved $4^{\text {th }}$ January, 2015 From www.ccc.de/en/updates/2009/wahlcomputer-urteil-bverfg

[33] The Voting News. 2012. Belgium: Decision to Use SmartmaticVoting MachinesRignites E-voting Debate. Retrieved $16^{\text {th }}$ April, 2014. From http://thevotingnews.com/belgian-regions-decision-to-use-new-voting-machines-reignites-evoting-debate-cio-com/

[34] Mercuri, R. 2001. Electronic Voting. Retrieved $6^{\text {th }}$ December, 2012 From http://www.notablesoftware.com/evote.html

\section{Author biography with Photo}

Ben Beklisi Kwame Ayawli has taught Information Technology courses including Computer Applications, Database Management Systems, Multimedia Application Development, Web Engineering, Internet-Enabled Application Development and many others since 2008 at Sunyani Polytechnic, Ghana, Valley View University and University of Education, Ghana (Distance program). He is also into the development of web applications including E-Voting System, School Management System, Laundry Management System, Microfinance Management System etc. He obtained a B.Ed in Information Technology from University of Education, Winneba-Ghana and MSc in Information Technology from Sikkim Manipal University, India. He is currently a lecturer and the ICT Director of Sunyani Polytechnic, Ghana. Web application development and security is his research interest. He is currently a PhD student in Information Technology conducting a study in the area of Electronic Voting. 